\title{
QUESTóES PEDAGóGICAS
}

\author{
NOÇÕES DE NUMISMÁTICA. \\ CONDECORAÇÕES (II).
}

(Continuação) .

II

\section{ORDENS MILITARES E HONORfFICAS.}

Nomenclatura das condecorações. Como se teriam originado as Ordens Militares de Cavalaria da Idade Média. Resumo histórico de algumas Ordens monlásticas guerretiras fundadas na sua quase totalidade durante as Cruzadas. Outras Ordens Militares de Cavalaria instituídas durante a Idade Média. Conceito sôbre as Ordens de Cavalaria. Classificação 'das condecorações. Classificação das medalhas condecorativas. Medalhas comemorativas. Plaquetes. Colares. Medalhas esportivas. Graduação das Ordens Honoríficas. Como se distinguem os diversos graus das Ordens. O uso das cond ecorações. Introdução ao estuddo das Ordens honoríficas brasileiras.

\section{NOMENCLATURA DAS CONDECORAÇÕES.}

Condecoração é um sinal de distinção honrosa, símbolo ou insignia civil ou militar, oriunda das monarquias e hoje extensivas às Repúblicas, com o fim exclusivo de premiar serviços. E' uma forma elegante de recompensar e ser recompensado, levando-se em consideração o mérito de cada agraciado.

Condecorar ou agraciar é distinguir com insígnias, isto é, conferir tôda e qualquer medalha civil ou militar pendente de fita ou bandas.

Miniatura é o modêlo reduzido das condecoraçōes ou das medalhas condecorativas; são usadas presas a um broche apropriado de forma inglêsa ou a um trancelim de ouro do modêlo francês, colocadas na mesma disposição das insígnias, isto é, alinhadas de dentro para fora, uma ao lado da outra. As miniaturas podem ser enriquecidas com pedras preciosas, obra de joalheria. 
Roseta é o laço ou nó de fita em forma de rosa, constituída pela fita da condecoração e usada pelos agraciados na botoeira da lapela em traje civil.

Barreta é uma barra de metal revestida de um ou mais pedaços de fita, de $35 \mathrm{~mm}$. de largura por $10 \mathrm{~mm}$. de altura; êsses pedaços correspondem às côres das fitas de que pendem as insignias recebidas pelos agraciados e são usadas pelos militares; são colocadas em fila de três ou quatro por cima do bôlso superior, do lado esquerdo do uniforme.

Passador é uma peça retangular de metal, integrante da medalha e por onde atravessa a fita da condecoração; o passador geralmente indica pelos emblemas que ostenta, o tempo de serviço, prêmios ou qualquer outro motivo.

Crachá, placa ou medalha que os grã-cruzes e comendadores costumam trazer ao peito como distinção honorífica.

Condecoração, venera.

Venera, insígnia ou medalha decorativa dos cavaleiros e outros graus das ordens honoríficas.

Condecoração.

Por comendador designava-se em Portugal em épocas afastadas os provedores, diretores ou curadores dos hospitais que existiam junto de algumas comunidades religiosas com bens particulares e rendimentos separados.

Comenda era um benefício rendoso que no passado se concedia aos nobres e aos cavaleiros das diversas Ordens Militares de Cavalaria.

Os primeiros reis portuguêses dividiam pelos nobres e soldados as terras conquistadas aos mouros, como fêz $\mathrm{D}$. Afonso Henriques no campo de Valada em 1147, por ocasião da conquisti de Lisboa.

Além disso, costumavam fazer doações de territórios, vilas ou cidades, como prêmio de serviços militares ou por motivo de afeição e parentesco. Não só aos nobres, mas também aos mosteiros, catedrais e Ordens Militares, como aos cavaleiros das Ordens do Templo ou Templários, aos de Avís e aos de Santiago da Espada, mas exigindo em troca, a obrigação de defesa e proteção dessas terras.

O desastre de Alcácer-Quibir em 4 de agôsto de 1578 em Marrocos e o desaparecimento do rei $\mathrm{D}$. Sebastião que comandava o exército português nessa famosa batalha, veio dar um golpe profundo nas antigas Ordens Militares de Cavalaria em Portugal. Quando a Corôa Portuguêsa absorveu a administração e o mestrado de tôdas essas Ordens, ficou senhora das comen- 


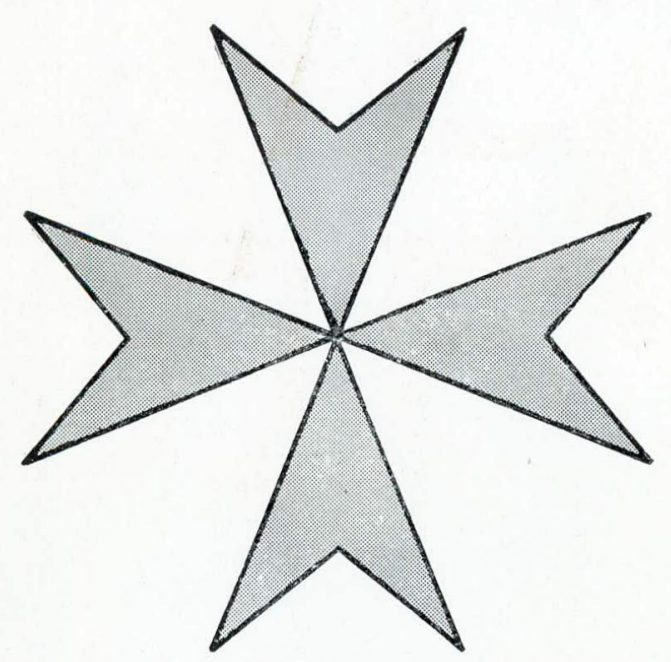

CRUZ DA ORDEM DE MALTA

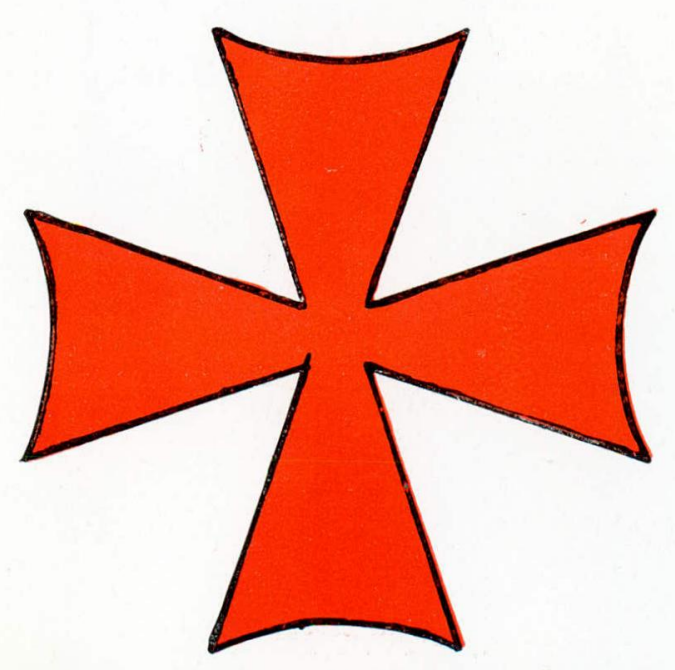

CRUZ DOS TEMPLÁRIOS

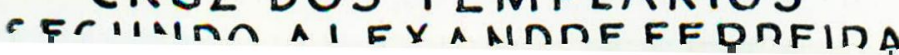

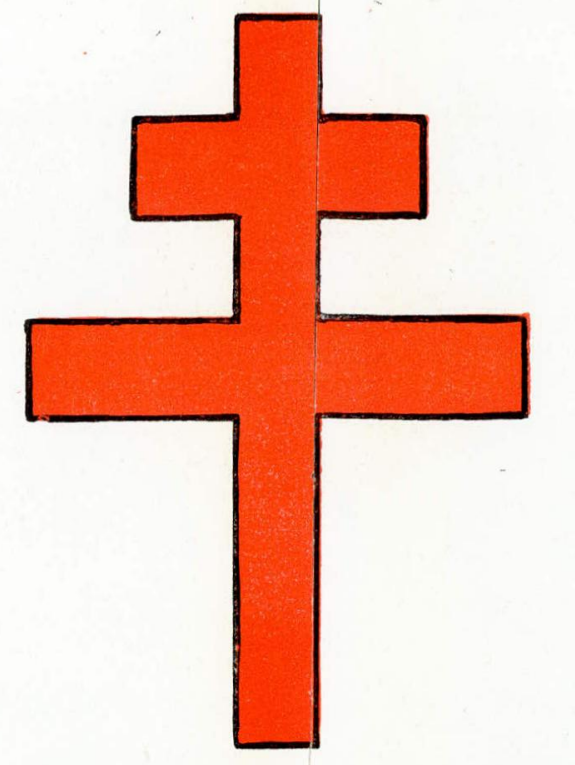

CRUZ PATRIARCA. DOS TEMPLARIOS (PRIMITIVA CRU: DA ORDEM)

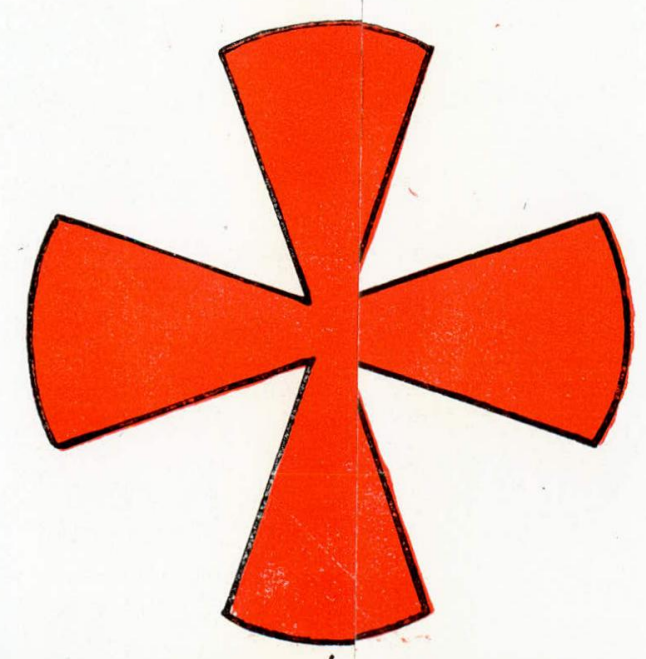

CRUZ DOS TEMPLÁEOS COMO APARECE NOS ESTATUTOS DANRDEM EM 1.705, EXISTENTE NOS ARUIVOS NACIONAIS

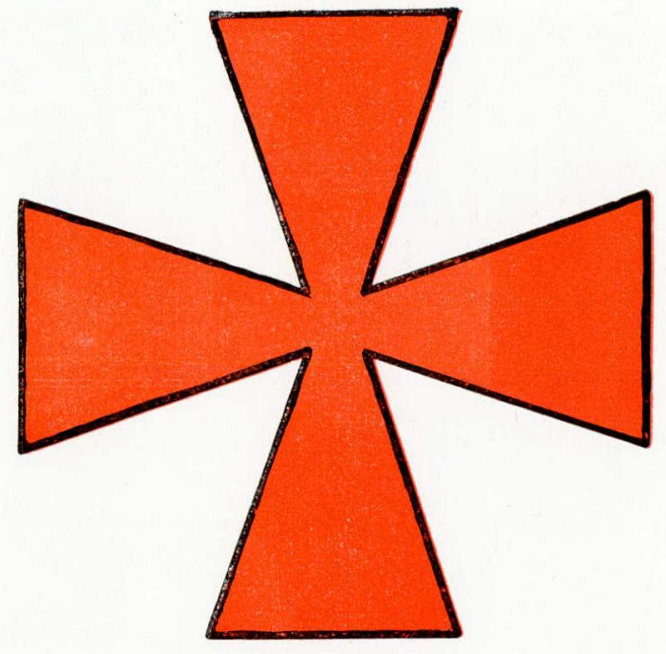

CRUZ PÁTEA DA ORDEM DOS TEMPLÁRIOS CONCEDIDA PELO PAPA EUGENIO III EM 1.147

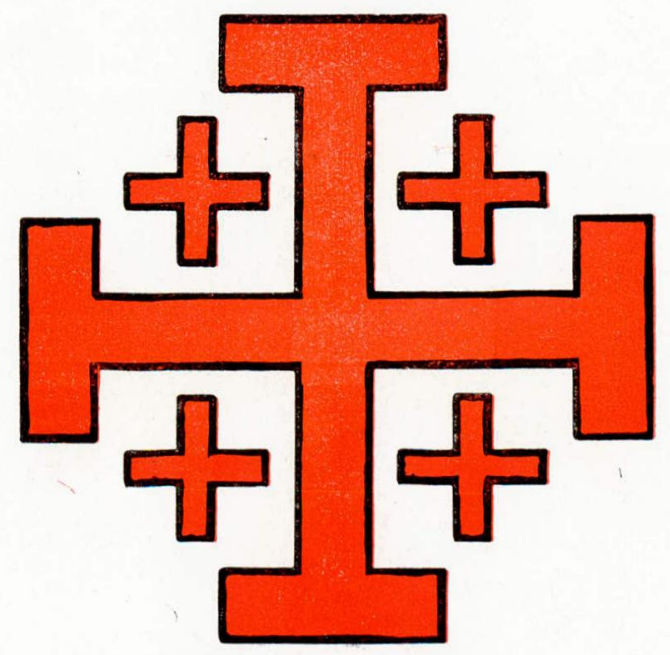

CRUZ DA ORDEM DO SANTO SEPÚLCRO 
das que ela mesma distribuira como recompensa ou como dádiva a quem julgara merecedores de tais merrcês.

Depois que as comendas rendosas foram extintas por decreto de 1834 da rainha D. Maria II, de Portugal, o título de comendador ficou apenas como distinção honorífica, o terceiro grau de algumas Ordens Militares ainda hoje existentes.

Por hábito entendia-se no passado a entrega a alguém de uma insígnia ou condecoração; dizia-se por exemplo: o hábito de Cristo. Nos tempos modernos entendemos ter sido alguém condecorado com um dos graus dessa Ordem ou de outra qualquer.

"A lembrança de sua origem cristã conservou-se através dos centenários na tecnologia das condecoraçōes. 'Diz-' se "que uma pessoa récebeu o hábito da ordem tal $e$, no entanto, as ordens 'já não obrigam a vestir o hábito mo'nástico, nem a fazer votos religiosos. Diz-se que foi concedida a uma pessoa a venera de certa ordem, isto é, a vieira ou concha e já ninguém mais pendura de sua cápa a vieira das longas peregrinaçóes a Roma, à Terra Santa ou a Compostela, Os condecorados continuam a ser cavaleiros e comendadores, quando não mais combatem a cavalo nem recebem comendas ou benefícios eclesiásticos” (16).

\section{COMO SE TERIAM ORIGINADO AS ORDENS MILITARES DE CAVALARIA DA IDADE MÉDIA.}

Das Cruzadas - Sublimação máxima do espírito da famosa Cavalaria Medieval foram as Cruzadas empreendidas durante o's séculos XI, XII e XIII.

Deu-se-lhes o nome de Cruzadas, porque aquêles que delas faziam parte eram denominados Cruzados, das cruzes de diferentes côres que traziam no ombro direito e nas bandeiras, sendo a dos franceses, vermelha; branca a dos inglêses; verde a dos flamengos; prêta a dos alemães e amarela a dos italianos.

As Cruzadas no Oriénte foram em número de oito, a saber:

1a. Cruzada - desde 1095 a 1099, no Pontificado de Urbano II, pregada por Pedro-o-Eremita e comandada por Godofredo de Bouillon.

(16). - Gustavo Barroso, Introdução a técnlca de museus. Publicação do Museu Histórico Naclonal (Ministérlo da Educacão e Cultura) :.: Rlo de Janeiro, 1947. 
2a. Cruzada - desde 1145 a 1148, no Pontificado de Eugêtio III, pregada por São Bernardo e comandada por Conrado III, imperador da Alemanha e Luís VII, rei de França.

3a. Cruzada - desde 1188 a 1192, no Pontificado de Clemente III, pregada por Guilherme, arcebispo de Tiro e dirigida por Frederico Barba-roxa, imperador da Alemanha, Filipe-Augusto, rei de França e Ricardo Coração-de-Leão, rei da Inglaterra.

4a. Cruzada - desde 1195 a 1198, no Pontificado de Celestino III, pregada por Foulques, cura de Neuilly e capitaneada pelo marquês de Mont-ferrat.

5a. Cruzada - desde 1198 a 1204, no Pontificado de Inocêncio III e comandada por André III, rei da Hungria e João de Brienne, cavaleiro francês.

6a. Cruzada - desde 1120 a 1240 , no Pontificado de Honório III e de Gregório IX e comandada por Frederico II, imperador da Alemanha.

7a. Cruzada - desde 1248 a 1255, no Pontificado de Inocêncio IV e de Alexandre IV, pregada pelo cardeal Eudes e comandada por São Luís, rei de França.

8a. Cruzada - desde 1269 a 1270 , no Pontificado de Clemente IV, pregada pelo próprio Papa e capitaneada pelo mesmo monarca (17).

As Cruzadas eram as expedições religiosas e militares conduzidas pelos Cristãos do Ocidente, contra os infiéis do Oriente, com a finalidade de restaurarem os Santos Lugares tirando-os das mãos de seus bárbaros inimigos e conquistadores que eram os maometanos, ou por outras palavras, foram as guerras heróicas da Idade Média.

Debaixo do ponto de vista religioso formou a Europa no tempo das Cruzadas, uma espécie de República cristã ou federação de Príncipes presidida pelo Papa.

A Europa, ainda que bárbara no tempo das Cruzadas, apresentava um espetáculo único na História: o fervor ardente e a união de todos os povos cristãos numa mesma fé e num mesmo pensamento. A fé de Cristo, o pensamento de libertar o seu sepúlcro em poder dos infiéis e a proteção aos peregrinos que ali iam tributar suas homenagens. A isto, juntava-se o terror causado pelos progressos ameaçadores dos turcos seldjúquidas e pela seita tenebrosa e fanática dos ismaelitas que, sob a autoridade de um chefe misterioso denominado o velho da montanha, residente na fortaleza de Alamut, estendia o seu domínio pela

(17).. - F. Noel et Carpentier, Nouveau dictionaire des origines, inventions et découvertes. 
maior parte dos castelos e lugares fortes das montanhas, entre o mar Cáspio e o Mediterrâneo.

As conseqüências destas expedições foram várias, segundo o modo como a olharmos. Assim, encarando-as pelo lado político, comercial, industrial, intelectual e religioso, temos:

Conseqüências políticas: pelo lado político, estas expedições puseram têrmo às guerras particulares que dilaceravam a Europa; enfraqueceram o feudalismo que com os seus elos acorrentava a sociedade medieval; engrandeceram a autoridade real, aumentando os seus domínios pelo enfraquecimento dos grandes vassalos, temíveis rivais da realeza e tirânicos opressores do povo; fomentaram o movimento de emancipação das comunas, como conseqüência do abatimento dos senhores feudais; aproximaram os povos pela convivência que senhores e vassalos por muitos anos tiveram no Oriente; deram à Europa a unidade que a engrandeceu; poliram os costumes e provocaram a ilustração.

Conseqüências comerciais: pelo lado comercial, desenvolveram as relações marítimas entre as diversas partes do mundo; engrandeceram muitas cidades da Itália e da liga hanseática pelo comércio de especiarias e outros produtos do Oriente.

Conseqüências industriais: pelo lado industrial foram muitos os progressos de novas indústrias colhidos naquelas paragens, tais como o de lavrar os metais, o fabrico de certos tecidos, o aperfeiçoamento do vidro, a moagem por moinhos de vento e certas culturas como a de sêda e a cana de açúcar.

Conseqüências intelectuais: pelo lado intelectual, não só as letras e as ciências se desenvolveram, tomando a poesia uma nova forma pela criação dos romances de cavalaria, mas muitos e preciosos manuscritos árabes, gregos e siríacos nos vieram daquelas longínqüas regiões. A ignorância, que fazia um dos títulos de nobreza naquela idade, foi substituída pela cultura do espírito, começando então a fundação das principais universidades da Europa: as de Pádua e Paris, 1180; a de Cambridge, 1229; a de Nápoles, 1230; a de Viena, 1238; a de Salamanca, 1240 e a de Lisboa, 1290 .

Conseqüências religiosas: pelo lado religioso, enfim, se as Cruzadas pareceram firmar a onipotência papal, também marcaram o princípio da decadência do poder temporal dos papas..

Roma, tornando-se o lugar de passagem de quase tôda a Cristandade, foi visitada por grande número de habitantes da Europa. Os Cruzados presenciaram o espetáculo dos seus costumes e da sua política e muitas vêzes reconheceram o interêsse pessoal nos debates religiosos; estas considerações, juntas 
as desenvolvimento intelectual dos povos, inspiraram a homens: audazes sentimentos de liberdade até então desconhecidos.: Por, isso vemos, depois das Cruzadas, os Pontífices mais sóbrios no emprêgo da terrível arma da excomunhão com que faziam tre-mer os reis e os povos. O abatimento do fanatismo e a tolerância religiosa foram as conseqüências imediatas desta resolição da Santa Sé.

Das Ordens de Cavalaria. Vejamos de que maneira se teriam originado as Ordens honoríficas ou Ordens de Cavalaria; algumas das quais subsistem em nossos dias, embora com seus, regulamentos modificados:

Vindas quase na sua totalidade dos tempos das Cruzadas, seus membros estavam sujeitos aos votos e regras monásticas; eram regidas por Grão-mestres, Priores, Bailios e Comendadores e distinguiam-se pelo: hábito branco vestido por cima da.armąura, sôbre o qual se destacava a Cruz da Ordem a que pertenciam.

Pedro-o-Eremita, varão nobre, natural de Amiens, renunciando à carreira das armas, vestiu o burel de peregrino e foi visitar os Santos Lugares; comovido com a tristíssima sorte dos: cristãos da Palestina que viviam sob o férreo jugo dos infiéis e indignado com o abandôno e profanação do sepulcro de Jesus, depois de ter procurado Simeão, patriarca de Jerusalém, dirigiu-se a Roma a fim de obter do: Papa Urbano II autorização: para pregar uma Cruzada contra os opressores e proteger as relíquias sagradas da Terra Santa.

Pedro tinha a eloqüência e a autoridade de um tribuno popular. De pequena estatura, magro, trigueiro, de grandes barbas grisalhas, andava vestido de lã, com o seu hábito monacal e descalço. Andava sempre montado num burro. A sua palavra ardente contando ao Sumo Pontífice os sofrimentos passados pelos peregrinos, despertaram o interêsse de Ur-i bano II. E por Bula Pontificial de 1095, era organizada a Primeira Cruzada.

Em Clermont, na praça pública, Urbano II conclamava a Europa cristã a alitar-se. Pedro, por sua vez, começou suas prédicas no Berry, província limítrofe do Auvergne e atravessando o domínio capetíngio, passou à Lorena e daí à região romana. Este apêlo excitou tôda a Europa no desêjo de vingança. De todos os pontos da Cristandade afluiam nobres cavaleiros prontos para a bélica emprêsa. Entre êstes, Godofredo de Bouillon, duque da Baixa-Lorena; Balduino e Eustáquio, seus irmãos; Hugo, conde de Vermandois, irmão do rei de França, Filipe I; Roberto, duque da Normandia; Roberto, conde de Flan- 
dies; Raimundo, conde de Tolosa; Marcos Boemundo, príncipe de Tarento e posteriormente de Antioquia e seu primo Tancredo da Sicília, mais tarde príncipe de Tibiriades ou Galiléia, ambos chefes dos normandos da Itália e o próprio Pedro, figura preponderante da Primeira Cruzada que arrastou atrás de si milhares de Cruzados (18) .

Godofredo de Bouillon, cristão fervoroso, tomou a cruz e à frente de alemães e franceses do norte, formando numeroso exército, parte pelo ano de 1096 em direção a Constantinopla, onde Aleixo I Comneno, imperador grego do Oriente sofria tremenda pressão dos turcos. Atravessando o Bósforo na sua impetuosa investida, cerca Nicéia e Doriléia, tomando-as e faz entrega dessas cidades a Aleixo I; continuando sua marcha, entra triunfante nas vastas regiões da Asia Menor, atravessa a Síria, conquista Antioquia e nas planícies desta cidade derrota, pondo em debandada poderoso exército muçulmano. Aqui, espera a chegada dos demais Cruzados, quando resolve atacar Jerusalém onde penetra em meio de tremenda luta.

A Godofredo de Bouillon é oferecida a corôa do novo reino cristão o que êle recusa dizendo:

"onde Cristo havia cingido uma corôa de espinhos, não podia êle ostentar uma corôa de ouro".

Apenas tomou para si o título de barão do Santo Sepulcro (19) .

Os limites do novo reino eram breves: Jerusalém, Jafa e niais umas vinte cidades circunvizinhas formavam os domínios cristãos na Palestina. Esse reino fundado pelos Cruzados era, pois, uma colônia francesa pela língua, pelos costumes, organização militar e a administração da França feudal ali adaptadas.

Não obstante, o fervor religioso dos peregrinos crescia, e com êle o seu número na visita ao santuário da Cristandade. Entre os muitos que aí chegaram, encontrava-se um certo Gérárd de Tunc, natural da cidade de Martigues, na Provença, homem extremamente piedoso e respeitado até pelos sarracenos, chegando mesmo a conquistar o título glorioso de "Pai dos Pobres". Fazendo-se frade em Jerusalém, foi o superior do mosteiro aí levantado por alguns negociantes de Amalfi, em 1050, para alívio dos peregrinos. Enquanto Godofredo de Bouillon

(18). - Pedro-o-Eremita, nasceu em Amiens e morreu no convento de Neufmoustier, por éle fundado, próximo de Huy, pelo ano de 1115. Foi o princlpal pregador da Primeira Cruzada.

(19). - Godofredo de Bouillon, duque da Baixa-Lorena, nasceu em Baisy, perto de Genape, na Bélgica, pelo ano de 1058. Por morte de seu tio Godofredo-o-"Corcovado", recebeu do imperador Henrique IV o marquesado do 
cercava a cidade de Assur, Gérard caiu nas mãos dos muçulmanos, sendo prêso a uma cruz e exposto aos tiros dos cristãos. Sobrevivendo às suas feridas, fundava em Jerusalém um hospital a que denominou Ordem dos Irmãos Hospitaleiros de São João de Jerusalém, consagrado a todos os necessitados nas suas visitas aos Santos Lugares (20).

Esta Ordem foi aprovada no ano de 1113 pelo Papa Pasc cal II. Por morte de Gérard de Tunc, assumia a direção dos Hospitaleiros por votação unânime de seus companheiros e aprovação do Pontífice, Raimundo du Pay, chamado Raimundo de Saint-Gilles, conde de Tolosa e que fôra um dos primeiros a se alistar na Primeira Cruzada.

Entretanto, continuavam as lutas entre cristãos e muçulmanos. Raimundo, concebe então transformar a Ordem dos Irmãos Hospitaleiros em uma Ordem Militar de Cavalaria que, seguindo os ensinamentos de Santo Agostinho, batalhasse com bravura pela glória de Deus, livrando do domínio dos turcos os Santos Lugares. Essa idéia obteve a aprovação dos demais membros dos Hospitaleiros e sendo a receita muito superior à despêsa do hospital com a manutenção dos enfêrmos e órfãos foi resolvido aplicar-se o saldo na guerra contra os infiéis. $\dot{\mathrm{Pa}}$ $r: i$ êsse efeito, foram os Hospitaleiros divididos em três classes: a primeira, formada pelos nobres e destinada aos combates e proteção dos peregrinos; a segunda, composta de sacerdotes incumbidos dos serviços divinos e a última de irmãos sèrventes, encarregados de prestar auxílio aos cavaleiros e aos religiosos.

E no ano 1118, junto ao Santo Sepulcro em Jerusalém; surgia a primeira Ordem Militar de Cavalaria, a mais antiga do mundo, sob a denominação de Ordem Militar dos Hospitaleiros de: São João ou Freires do Hospital de São João.

Em 1120, o Papa Calixto II criava o título de Mestre dos Hospitaleiros, confirmando no cargo o cavaleiro Raimundo du Pay e dez anos depois o Pontífice Inocêncio II não só reconhecia a fundação da Ordem, como baixava novos regulamentos que subsistiram durante séculos.

Debaixo de organização semelhante, floresceram as demais Ordens Militares de Cavalaria monásticas-militares. Envoltos

Antuérpia, sendo depois investido no ducado de Bouillon. A sua história confunde-se com a da Primeira Cruzada. Derrotou os muçulmanos em Ascalon, falecendo na Palestina em 1100, aos quarenta e dois anos de idade.

20). - Gérard de Tunc, nasceu na.Provença, ou segundo outros nos Países-Baixos, pelo ano de 1040, falecendo em 1118. Foi honrado na sua ordem com 0 título de "Bemaventurado", sendo sua festa comemorada em $\theta$ de julho. 
nos seus mantos brancos sôbre a armadura, onde resplandecia a Cruz ordenada pelo Papa Eugênio II, começavam os Cavaleiros da Idade Média a escrever uma época brilhante da História que teve como símbolos: o Valor, a Fôrça e a Lealdade.

E' natural que as primeiras Cruzadas, criando para a Cavalaria Medieval uma época brilhante, precisasse para realçar e colorir os fatos e os seus heróis, de emblemas ou honrarias eqüivalentes ao impulso que animava os cavaleiros e assim, surgiram as Ordens de Cavalaria que iriam dar origem às Ordens honoríficas ainda hoje existentes em quase todos os países do mundo, inclusive o Brasil.

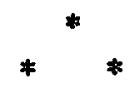

RESUMO HISTÓRICO DE ALGUMAS ORDENS MONASTICAS GUERREIRAS FUNDADAS NA SUA QUASE TOTALIDADE DURANTE AS CRUZADAS.

As Ordens Militares Religiosas a que deram origem as primeiras Cruzadas foram as seguintes:

$1 .^{\circ}$ - Ordem idos Cavaleiros Hospitaleiros de São João de Jerusalém, mais conhecida por Ordem de Malta.

2. - Ordem do Templo ou dos Cavaleliros Templários.

$3 .^{\circ}$ - Ordem Teutônica.

Ordem dos Cavaleiros Hospitaleiros de São João de Jerusalém. Foi instituída em 1118, em Jerusalém. Tinha por fim não só agasalhar os peregrinos cristãos que iam visitar os Santos Lugares e dar abrigo aos doentes, como lutar pela Fé. O nome de Cavaleiros de São João, veio-lhe de uma igreja com a invocação de São João Batista, que os Hospitaleiros edificaram com o produto das esmolas que de tôda a Europa afluiam a Jerusalém, conquistada esta cidade pelos Cruzados. Depois da perda da Terra Santa em 1291, refugiaram-se os Cavaleiros de São João de Jerusalém na ilha de Chipre, onde permaneceram até ao ano de 1310, em que tomaram a ilha de Rodes e nela se cc.nservaram até 1522; daí ficaram conhecidos por Cavaleiros de Rodes. Em 1530 chegaram à ilha de Malta, que o imperador Carlor V lhes deu para se estabelecerem, com o föro de um falcão cada ano aos reis de Espanha, a quem reconheceram como seus protetores. Desde então foram chamados Cavaleiros He Malta. Quando em 1798 Bonaparte se dirigiu para o Egito à frente de seu exército, apodera-se da ilha sem combate, uma vez que lhe é entregue debaixo do protesto de Ferdinando Hos- 
pech, seu último Grão-Mestre; e, enquanto duraram as guerras: napoleônicas, passou a ilha para o domínio inglês, até que o Tratado de Paz firmado em 1814, reconhecia a posse difinitiva da ilha pelo govêrno britânico.

Terminava dessa maneira a existência política da Ordem de Malta, embora o imperador da Rússia, Paulo I, a quem tinha sido conferido no mesmo ano de 1798 o Grão-mestrado da Ordem em conseqüência da abdicação de Ferdinando Hospech, tentasse reerguê-la sem resultado.

Transferindo-se então para Roma, Piø VII não fêz nomeação alguma, limitando-se a dispor que a Ordem, privada da ilha de Malta, fôsse provisòriamente regida por um Lugar-tenente do Grão-mestrado, eleito vitalìciamente por um ConseIho de Cavaleiros residentes na Itália.

A 12 de maio de 1827, o Papa Leão XII transferiu a sede da Ordem para o Estado Pontifício, até que Gregório VI autorizou definitivamente sua instalação em Roma; em 1854, Pio IX confirmou o Regulamento, modificado por Leão XIII em 1880, quando foi concedida à Ordem de Malta a igreja de São Basileu e o seu priorado no Monte Aventino. Nessa ocasião foi restabelecida a dignidade de Grão-mestre, sendo indicado. para êsse alto cargo Sua Eminência o cardeal João Batista Ceschi, de Santa Cruz de Trento, um dos mais ilustres membros do Sacro Colégio.

Desde 1530 a 1898, os Cavaleiros de Malta estiveram em guerra quase contínua com os turcos ou com os piratas barbarescos. Hoje, a Ordem de Malta subsiste como instituição honorífica. Compreende Cavaleiros de Justiça e de Devoção que devem dar provas de nobreza e Cavaleiros de Graça Magistral, nomeados pelo Grão-mestre por serviços prestados à Ordem. Nessas duas categorias contam-se os seguintes graus: Grãocruzes, Comendadores e Cavaleiros. Há ainda os Donatos, de classe inferior.

A insignia atual é a Cruz de Malta de esmalte branco e forcada sob uma corôa real de ouro, que indica soberania, pendendo de uma fita prêta. A Cruz dos Cavaleiros de Justiça, tem troféus sob a corôa. A dos Donatos, a ponta superior sem esmalte.'

Originária da Ordem Militar idos Hospitaleiros de São João de Jerusalém, depois Cavaleiros de Rodes e hoje Ordem Soberana de Malta, pela sua história e tradição milenar. envolta no respeito universal, como no passado, continua a estender sua proteção aos que sofrem oferecendo-lhes além do amparo 


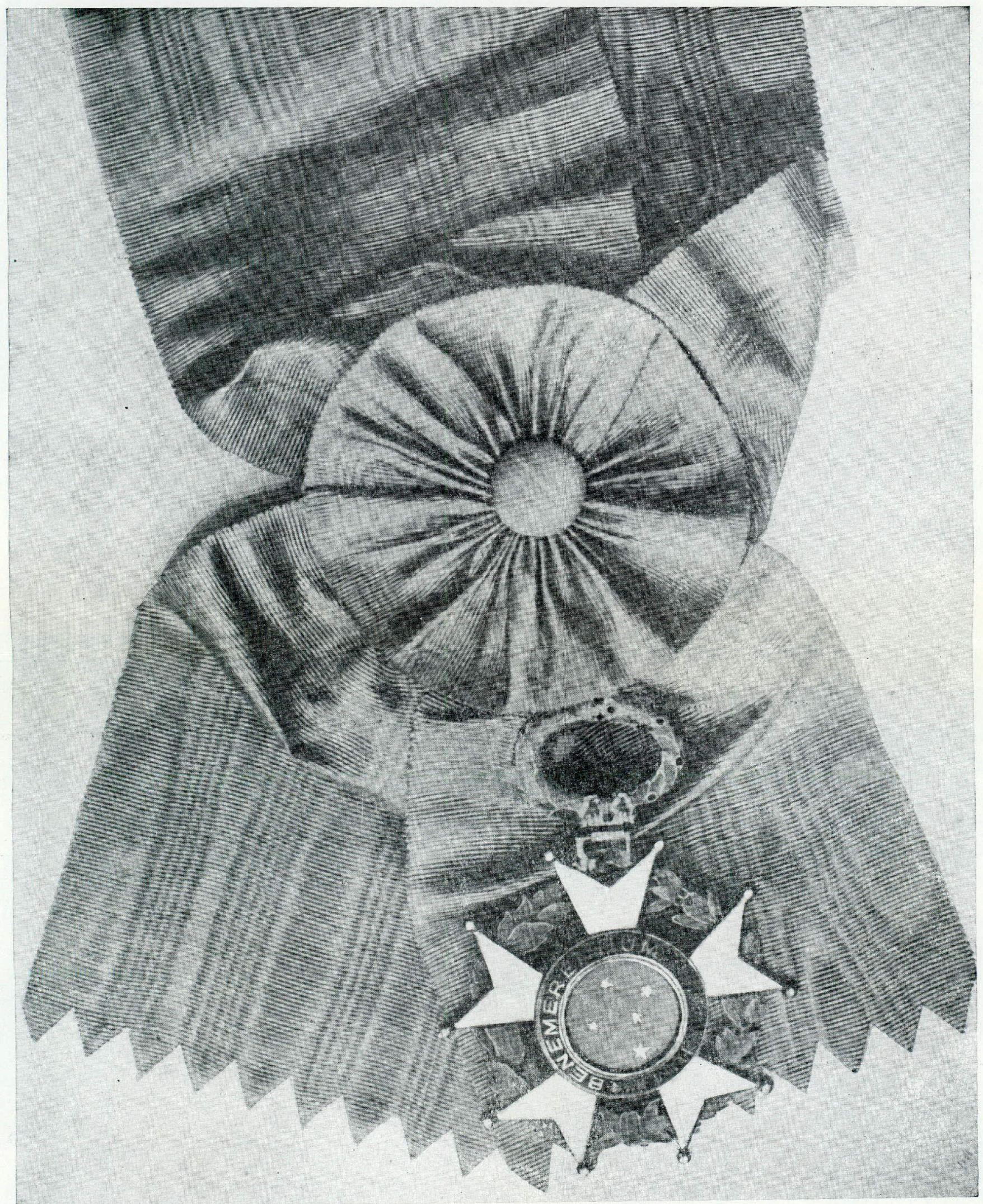

Fig. 6. - Ordem Nacional do Cruzeiro do Sul, insígnia atual. Fitão ou Banda a tiracolo com a insígnia da Ordem pendente. 

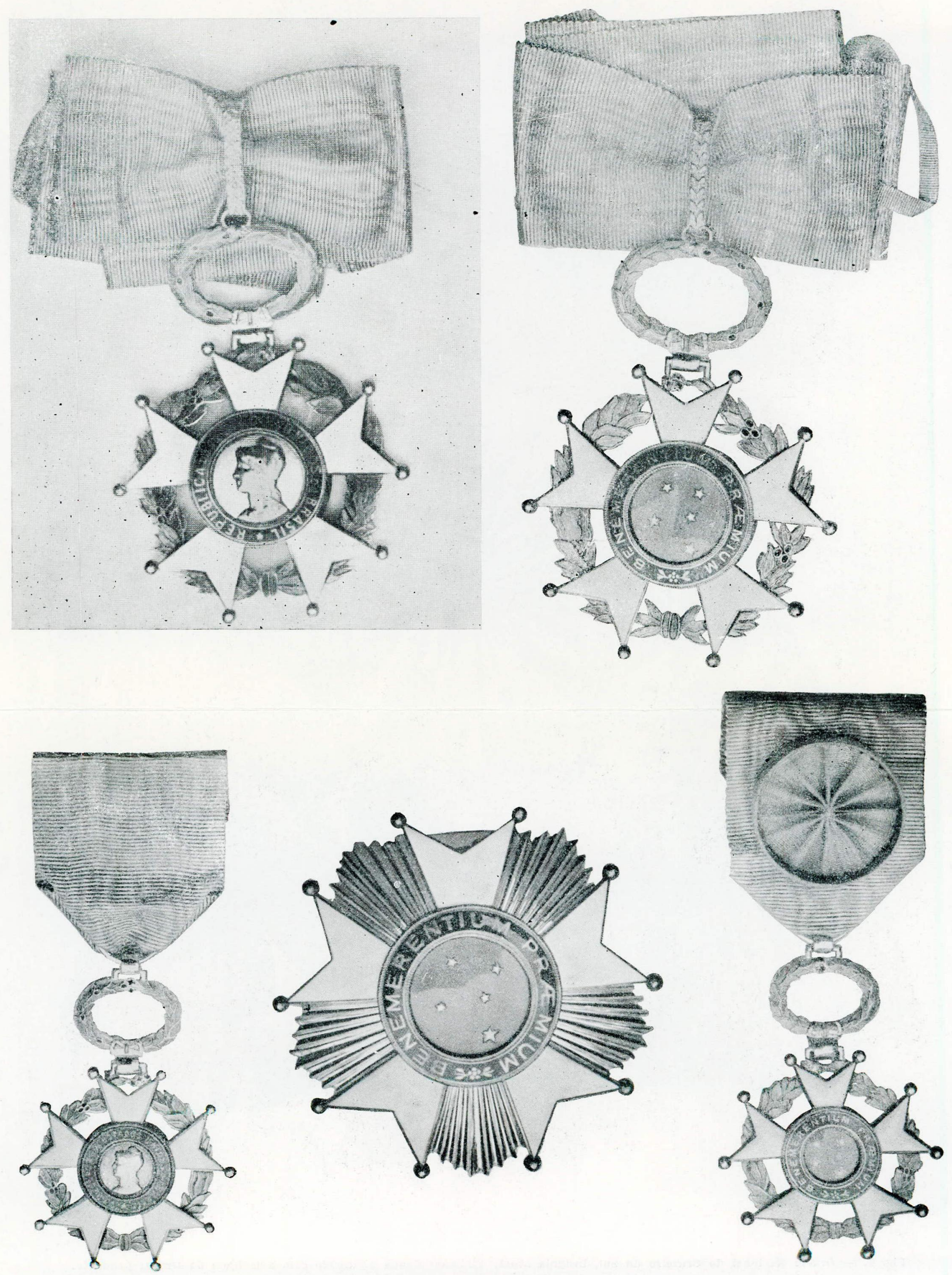

Fig. 7. - Ordem Nacional do Ćruzeiro do Sul, insígnias atuais: Grande oficial, anverso e reverso da condecoração.

Ofician, ruseta supre a ind com as cores da Ordem. 
material, aquêle em que se baseia o alicerce cristão: O Amor ao próximo como a nós mesmos.

Manto branco com uma Cruz de Malta vermelha, isto é, cic braços trapezoidais, à altura do ombro esquerdo. Mais tarde a cruz torna-se forcada, conservando os mesmos braços, e. é branca.

Ordem do Templo ou dos Cavaleiros Templários. Fundada por Hugo des Payens e oito cavaleiros franceses, no ano de 1118, em Jerusalém. Tiraram seu nome de um convento e hospital construído junto ao lugar onde antigamente estivera o templo edificado por Salomão em honra do Senhor.

O fim desta Ordem era defender da crueldade dos infiéis. os peregrinos cristãos que empreendiam por devoção, a viagศm a Jerusalém.

Espalhada por tôda a Cristandade, entrou em Portugal no. ano de 1125 , onde teve por seu primeiro Mestre a D. Gualdim Paes.

No ano de 1312 foi extinta pelo Papa Clemente V, a pedidc de Filipe-o-Belo, rei de França. Dos bens dos Templários em. Portugal, o rei D. Dinís em 1318, instituiu a famosa Ordem Militar de Nosso Senhor Jesus Cristo.

Manto branco com uma cruz vermelha de braços forcados.

Ordem dos Cavaleiros Teutônicos. Estabelecida em Jerusalém em 1128. Foi instituída pelos Cruzados alemães sob o nome de Irmãos do Hospital de Santa Maria dos Teutões, reorganizada por Frederico de Sabóia e aprovada como Ordem Militar pelo Papa Celestino III, em 1190.

Compreendia cavaleiros recrutados na nobreza, que faziam voto de pobreza, de castidade e de obediência; havia também padres ou capelães e irmãos serventes ou leigos. Esta Ordem prestou no Oriente os mesmos serviços que as Ordens do Templo e de São João de Jerusalém. Vinda para a Europa depois. da perda de Acre, fixou-se em Veneza, depois em Marienburgo em 1309 e por fim em Koenigsberg em 1466. Do Grão-mestre dependiam os mestres provinciais para a Prússia e para a Alemanha.

A Ordem dominou por muito tempo na Prússia, na Estônia, na Curlândia e na Pomerânia, apesar do antagonismo dos. 
coloneses e dos lituanos. O seu poderio foi aniquilado na batalha de Tanenberg, onde pereceu o grão-mestre Ulrico de Jungingen e a sua existência efetiva cessou no século XVI. Napoleão I aboliu-a em 1809 nos países da Confederação do Reno, nıas foi restabelecida em 1834 e depois reorganizada em 1840, em 1865 e em 1871.

A Ordem Teutônica foi admitida na Austria pelo Imperador Francisco José como instituto religioso de cavalaria independente, tendo sua sede em Viena. Era acessível às pessoas dos dois sexos, nobres e de religião católica. Foi extinta depois da última guerra.

Manto branco com uma cruz prêta.

A Ordem Militar dos Hospitaleiros de São João de Jerusalém em Portugal. Crato, vila portuguêsa situada no Alentejo, foi devastada pelos mouros em 716 e conquistada por D. Afonso Henriques em 1160, quando foi ela reedificada e povoada de cristãos aos quais foram concedidos muitos privilégios. Em 1232, reinando D. Sancho II foi a vila de Crato doada à Ordem com a condição de a repovoar e fortificar, principiando a vila em 1350 a readquirir parte de sua antiga importância, pois já era então sede dos Cavaleiros da Ordem de Malta. O primeiro Prior da Ordem Militar dos Hospitaleiros em Portugal, foi Mem Gonçalves.

Pouco a pouco foi aumentando o número de Cavaleiros no reino e os responsáveis pelo govêrno da Ordem, passaram a se intitular Priores do Hospital até 1340 e daí em diante Priores do Crato.

Em 1662 um exército castelhano comandado por D. João d'Austria, pôs cêrco à vila, que tinha uma pequena guarnição. Defendeu-se ela valorosamente enquanto pôde; mas, por fim, teve de render-se à superioridade numérica dos inimigos, que somavam 6.000 infantes e 4.000 cavaleiros. A população e os soldados que defendiam a vila salvaram a vida, fugindo o elemento civil para Portalegre e outras terras. Mas D. João enraivecido pela tenacíssima resistência que lhe fôra oposta, vingou-se praticando e deixando praticar tôda a qualidade de depredações. A vila foi saqueada e queimada, não havendo uma única casa que escapasse à fúria e à avidês dos invasores. $\mathrm{O}$ castelo foi arrazado e queimados os cartórios que guardavam muitos documentos importantíssimos para a história de Portu.gal e da Ordem de Malta. 
Foram dezoito em Portugal os grãos-priores do Crato, sendo o primeiro dêles, D. Alvaro Gonçalves Pereira, pai do grande condestável e o último o infante $D$. Miguel, depois rei, $D$. Miguel I.

Esta Ordem foi extinta em Portugal pelo decreto de 22 de agôsto de 1833, quando foram mandadas administrar pela Junta. dos Juros tôdas as Comendas que até então tinham pertencido à mesma Ordem.

Ordem do Santo Sepulcro. Antiga Ordem de Cavalaria de que erradamente se tem feito remontar a origem a Godofredo dc Bouillon ou a Balduino de Flandres, ou ainda a Santiago, primeiro bispo de Jerusalém. Pelo fim do século XV, Alexandre VI instituiu a Ordem Militar do Santo Sepulcro para honrar as pessoas nobres e ricas que se dirigiam em peregrinação à Palestina. Uma Bula de Pio IV deu, em 1561, ao guardião dos religiosos de São Francisco da Terra Santa, mais conhecido pelo nome de Padre Guardião da Terra Santa, o direito de fazer Cavaleiros do Santo Sepulcro. Esse direito foi confirmado por Pio IX ao patriarca de Jerusalém, guardião do túmulo de Cristo. Sua Santidade o Papa Leão XIII, por Carta Apostólica de 3 de agôsto de 1888, concedia ao patriarca e Grão-Mestre da Ordem, a faculdade de estender também às senhoras o recebimento das insígnias.

Compreende três classes: Grã-cruzes, Comendadores e Cavaleiros. A insígnia é uma cruz de ouro esmaltada côr de sangue, de forma potenciada, cantonada por quatro cruzes menores da mesma côr (é a representação das armas de Godofredo de Bouillon). E' suspensa de fita prêta de sêda chamalotada.

Esta condecoração não está encimada pela corôa, como homenagem a Godofredo de Bouillon que recusou ser coroado como primeiro rei latino de Jerusalém.

Ordem do Santo Sepulcro na Inglaterra. Criada por Henrique II, em 1174, aprovada em 1119 pelo Papa Inocêncio III. Foi dissolvida por ocasião do cisma anglicano e os cavaleiros que dela faziam parte ingressaram na Ordem de Malta.

Ordem do Santo Sepulcro em Portugal. Também chamada Ordem Militar e Canônica do Santo Sepulcro. Foi instituída ro tempo do conde $D$. Henrique. Sua mulher, a rainha D. Tereza, deu a esta Ordem, em 1123, as vilas de São Payo de Gouveia (também chamada São Payo da Serra) que depois outor- 
gou a seu filho D. Afonso I, Ladário e que depois passou a $\mathrm{D}$. Sancho I e Paços de Penalva.

Estes cavaleiros estabeleceram-se primeiro em Vila Nova de Penalva, que por isso se chamou Vila Nova do Sepulcro. Esta vila ficava sobranceira ao rio Om (hoje Dão) e na sua margem; pertencia a paróquia de Trancozelos que esteve anexa au castelo de Penalva e é hoje do concelho de Penalva do Castelo. No lugar onde existiu Vila Nova do Sepulcro, vê-se a antiqüíssima igreja e os vestígios do mosteiro da Ordem.

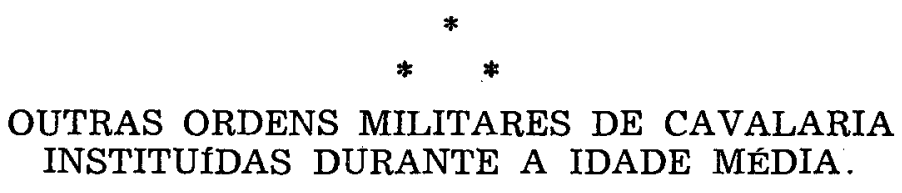

Ordem dos Cavaleiros Porta-Gládios ou Ordem dos Cavaleiros das duas Escadas, instituída em 1197 na cidade hanseática de Bremem, destinada a catequisar os povos pagãos do Báltico; manto branco com duas espadas vermelhas cruzadas.

\section{Na Península Ibérica.}

Durante muitos séculos, os cristãos combateram os muçulmanos na Espanha, numa verdadeira Cruzada e daí se originaram também várias Ordens de Cavalaria semelhantes às criadas na Palestina. Estas Ordens foram os baluartes em que se aroiaram as monarquias peninsulares na sua luta pela independência da Pátria.

Ordem Militar de Calatrava, fundada pelo rei Sancho III de Castela, em 1158; manto branco com uma Cruz vermelha de braços iguais, em ponta de lança ou inferior e, em flor de lís os superiores.

Ordem Militar de Santiago da Espada, fundada na Espanha em 1170; pela Bula do Papa Nicolau IV, em 1288, passou a ser considerada portuguêsa, quando foi eleito pelos seus cavaleiros primeiro Mestre, D. João Fernandes: manto branco com uma Cruz vermelha com a ponta superior em lança alargada e a inferior alongada; os outros braços terminam em flor de lís.

Ordem Militar de Alcântara, instituída na Espanha em 1156; manto branco com as insígnias iguais às da Ordem de Calatrava, pcrém, com a Cruz verde.

Ordem de Nossa Senhora de Monteza, fundada em 1136, pelc rei Jaime II, de Aragão; manto amarelo com uma Cruz verrielha num losango de ouro, encimado por um troféu de armas. 
Ordem Militar de Cristo, fundada pelo rei D. Denis, de Portugal, em 1319, substituindo a Ordem dos Templários portuguêse's; manto branco com a Cruz de Cristo vermelha de pontas alargadas, abertas em branco.

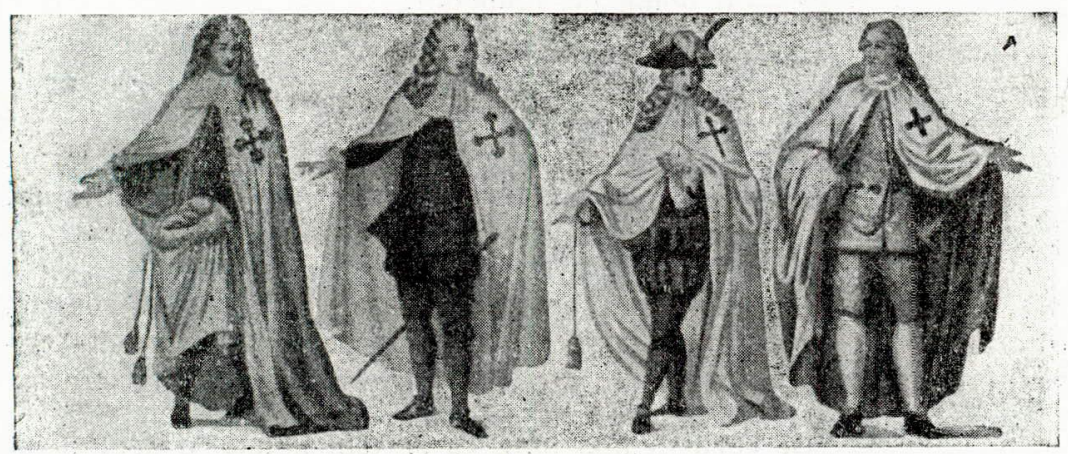

Fig. 5. - Ordens Peninsulares.

Cruzes nos mantos tradicionais dos Cavaleiros da Idade Média (trajes de Côrte). A primeira figura da gravura representa um cavaleiro da Ordem de Cavalaria, fundada por Sancho III de Castela, em 1158; a segunda, um cavaleiro da Ordem de São Bento de Avís, primitivamente chamada Ordem Nova, fundada pelo rei $D$. Afonso Henriques em 13 de agôsto de 1162 e instalada na cidade de Coimbra; dependia essa Ordem da de Calatrava existente na Espanha; a terceira, um cavaleiro da Ordem de São Tiago da Espada (São Tiago de Compostela) fundada por Fernando II, de Leão e Castela em 1170; a quarta, é um cavaleiro da Ordem de Monteza, instituída em 1316, por Jaime II de Aragão, em substituição à Ordem dos Templários em Espanha.

Ordem Militar de São Bento de Avís, originou-se da Ordem de Calatrava espanhola, sendo introduzida em Portugal pelo rei D. Afonso Henriques em 1162: manto branco com a Cruz da Ondem de Calatrava, verde, floreada nas quatro pontas.

\section{CONCEITO SÔBRE AS ORDENS DE CAVALARIA.}

O douto Gourdon de Genouillac, heraldista francês, autor de inúmeras obras sôbre a nobreza de França, assim se expressa sôbre o verdadeiro conceito em que deve ser conhecida a História das Ordens de Cavalaria: 
"O que convém conhecer na História das Ordens de Cavalaria que são atualmente conferidas na Europa ou já extintas, não é a forma da cruz, a cor da fita ou as dimensões da placa, informações que se encontram em todo o lugar, mas o que é preciso, é saber o seguinte:

$10^{\circ}$ - a data exata da fundação da Ordem;

$2 .^{\circ}$ - o nome do fundador;

$3 .^{\circ}$ - o motivo de sua criação;

$4 .^{\circ}$ - as diversas fases de sua existência;

$5.0^{\circ}$ - sua situação atual, se ela é ainda conferida;

$6 .^{\circ}$ - as causas que concorreram para a sua extinção, uma vez que não seja mais conferida" (21).

Razão tinha o erudito mestre em estabelecer essas regras, quando nos tempos modernos proliferam pretensas Ordens cavalheirescas que teimam em reviver Ordens há muito extintas.

"De certo tempo para cá se tem notado o deplorável fenômeno do aparecimento de pretensas Ordens cavalheirescas por obras e iniciativas privadas, que tem por fim substituir as formas legitimas de honorificência cavalheiresca. Como uma vez já se advertiu, estas assim chamadas ordens, assumem o nome seja de Ordens que realmente existiram, mas extintas há séculos, seja enfim de ordens verdadeiramente ficticias e que jamais tiveram precedente algum na História. Para maior, pois, confusão de idéias daqueles que ignoram a verdadeira história das Ordens Cavalheirescas e de sua evolução jurídica, estas iniciativas privadas que se declaram autônomas, vêm também atribuindo títulos que tiveram sua razão de ser no passado, ou que foram próprios de Ordens autênticas aprovadas a seu tempo pela Santa Sé. Por isso, com uma terminologia quase monótona, estas assim chamadas ordens, se atribuem nada mais nada menos que o título de Sagradas; Militares, Eqüestres, Cavalheirescas, Constantinianas, Capitulares, Soberanas, Nobiliares, Religiosas, Angélicas, Celestes, Lascárides, Imperiais, Reais, etc." (22).

(21). - Nicolau Júlio Henrique Gourdon de Genouillac, romancista e heraldista francês, nasceu em Paris (1826-1898). Consagrou-se a trabalhos respeitantes à nobreza de França, sendo suas principais obras: Gramática Heráldica; Dicionário Histórico das Ordens de Cavalaria; Dicionário dos feudos, senhorios, castelanias da antiga França; Os mistérios do brazão, da nobreza e do feudalismo; As ordens religiosas desde os primeiros tempos do Cristianismo até nossos dias; $A$. arte heráldica.

(22). - Advertência publicada pelo L'Osservatore Romano, órgão oficial da Santà Sé, em 22 de março de 1953, num artigo intitulado "Precisazione". 


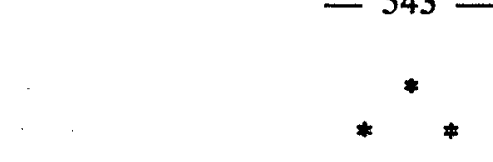

CLASSIFICAÇÃO DAS CONDECORAÇOEES.

F. F. Steenackers, membro da Société de l'Histoire de France, em seu magnífico trabalho sôbre Ordens de Cavalaria, assim se refere à classificação das condecorações:

"As Ordens de Cavalaria podem ser divididas em quatro classes bem distintas, que seguem a regra geral e a marcha histórica do progresso social.

1.0 - Ordens fabulosas. Puras fábulas ou lendas que se perdem na noite dos séculos. Elas estão para os povos modernos, como para a Grécia os tempos heróicos, quer dizer, aquêles tempos em que a fábula se misturava à História.

Tais são as Ordens da Santa Ampôla, por ocasião do batismo de Clovis e a da Genette, lembrança da civilização salva por Carlos Martel, em Poitiers. A primeira teria sido instituida no ano 496 e a segunda em 735 .

2.9 - Ordens Hospitalares Militares e Nobiliárquicas. As que na maior parte nasceram na Terra Santa, do momento das Cruzadas e do poder dos Papas.

Nessa época, a Santa Sé era o centro da Cristandade; os guerreiros abrigados sob o estandarte da Cruz, recebiam do Papa privilégios que os isentava de tôda e qualquer dependência com a Igreja. As Ordens Militares Religiosas; perpetuando as Cruzadas, eram milicias papais, um exército eclesiástico permanente: Os cavaleiros não deviam cultivar o amor pátrio para que êste não se antepusesse aos interêsses do Papa; viviam nos campos de batalha do Oriente ou nas propriedades que as Ordens possuiam espalhadas na Europa; os cavaleiros não tinham outra familia senão seus irmãos da milicia e por pátria, o seu devotamento a Roma.

“Tais são os Cavaleiros do Santo Sepúlcro, os Hospitaleiros de São João de Jerusalém, de São Lázaro, os Templários, etc.

A esta classe estão ligadas ainda as Ordens que tinham por finalidade as Cruzadas internas contra os heréticos, como a Ordem da Milícia de Jesus Cristo, os Porta-Cruzes ou Ordem da Santa Cruz, etc.

Uma contradição assás singular se encontra muito freqüentemente em tôdas as Ordens que parecem ter tomado o Evangelho por código; o esquecimento da igual- 
dade perante Deus e a exigência de provas de nobreza exagerada de todos os seus membros. A destruição dos Templários, trouxe o golpe mortal a essa organização.

3.0 - Então apareceu a terceira classe das Ordens de Cavalaria, as Ordens Reais e Nobiliárquicas. E' muitas vêzes na mão dos reis uma espécie de moeda honorifica ou instrumento de política para lutar contra seus vassalos ou soberanos vizinhos; nesta classe, estão incluídas a Ordem da Estrêla ou da Cása Nobre, sob Joáo II, eqüivalente à Ordem da Jarreteira, na Inglaterra; a Ordem de São Miguel, correspondente à Ordem do Tosão de Ouro da Borgonha; a Ordem do Espírito Santo, criada em face da" Liga. Como no periodo precedente, exigiam-se dos titulares foros de nobreza e provas de religião.

Pouco a pouco a. sociedade se organiza, dando também um concurso moral precioso com seu..sangue vertido nos campos de batalha; três ou quatro mil soldados nada são perto de milhares de cidadãos que compõem um povo. E' preciso, enfim, recompensar todo o mundo segundo o seu mérito e não mais o acaso do nascimento ou da diferença de religiăo.

$4 .^{\circ}-$ Esste pensamento produzirá o quarto periodo ou o das Ordens Igualitárias ou Democráticas, que deixam distinguir $o$ do militar, para não ver senão uma nação. Elas são destinadas a recompensar o mérito e não os vícios que agradam; começaram sob o reinado que São Simão denominou "o reino da vila burguesa" com a Ordem de São Luís, tão justamente chamada por Lemontey, de "obra-prima da idade madura de Luís XIV"; depois sob Luís XV, a Ordem do Mérito Militar.

A Assembléia Constituinte, que procurava fazer tabua rasa do passado, se inclina com respeito diante dessas criações um tanto democráticas. A idéia, nós o veremos, é ainda bem imperfeita, mas o germe está lançado e meio século depois êle produzirá a Legião de Honra, a Medalha Militar, as Palmas Universitárias, as medalhas do devotamento, quer dizer, recompensas graduadas para todos os serviços, para todos os méritos, para tôdas as vịrtudes, sem exceção de classe ou de crença" (23).

(23). - F. F. Steenackers, Histoire des ordres de chevalarie et des distinctions honorifiques en France, Parls, 1867. 


\section{CLASSIFICAÇÃO DAS CONDECORAÇŌES.}

De uma maneira geral as condecorações se classificam da seguinte maneira:

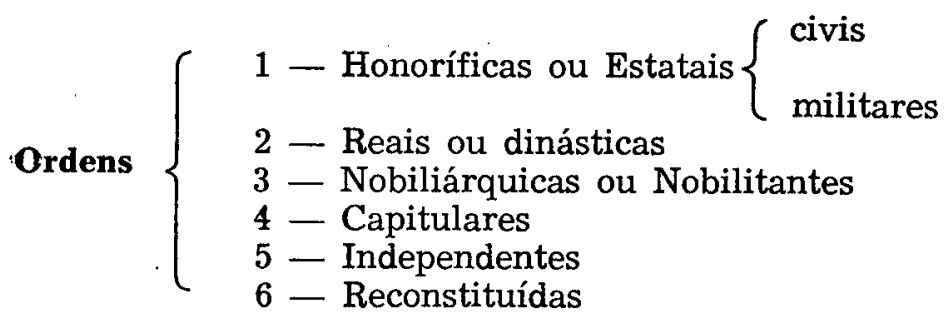

1 - Ordens Honorifficas ou Estatais são as transformações porque passaram as antigas Ordens de Cavalaria, mas pertencentes a um Estado soberano; são destinadas a recompensar serviços relevantes prestados à Nação por civis ou militares ou a homenagear figuras distintas que se tenham destacado nos vários setores da sociedade, a critério dos respectivos governos.

2 - Reais ou Dinásticas são as Ordens de Côrte, as que têm - grão-mestrado hereditário ou seja a sucessão estabelecida na mesma família. Algumas destas Ordens conferem graus nobiliárquicos.

3 - Nobiliárquicas ou Nobilitantes ou Nobiliárias são com fr. eqüência denominadas nobiliárquicas, isto é, pertencentes à robreza.

4 - Capitulares em que a sucessão do grão-mestre deve darse por eleição pelos cavaleiros reunidos em Capítulo.

5 - Independentes, privadas ou autônomas, que não são conferidas pelo Estado e nem por êsse reconhecidas.

6 - Reconstituídas são as que aparecem usando o nome de outras Ordens, o que muitas vêzes não quer dizer que não sejam as mesmas. Estas podem causar confusão apropriandose ilìcitamente de Ordens já extintas.

\section{CLASSIFICAÇÃO DAS MEDALHAS CONDECORATIVAS.}

Estas medalhas pendentes de fitas, podem ser classificadas da seguinte maneira: 
Medalhas condecorativas militares

$$
\left\{\begin{array}{l}
1 \text { - de campanha } \\
2 \text { - tempo de serviço } \\
3 \text { - instrução militar } \\
4 \text { - comemorativas } \\
5 \text { - premiais }
\end{array}\right.
$$

1 - De Campanha, instituídas por decreto do govêrno e destinadas a premiar todo o indivíduo que se tenha destacado for ações de guerra em defesa da Pátria.

2 - Tempo de Serviço, criadas por decreto governamental com o fim de premiar os bons serviços prestados por oficiais e praças das classes armadas, sem falta que os desabone, nos períodos de $10,20,30$ e 40 anos.

3 - Instrução Militar, destinadas a galardoar o primeiro classificado nos concursos militares ou de instrução militar.

4 - Comemorativas, concedidas por fôrça de decretos-leis, portarias ou Aviso Presidencial, Ministerial ou Municipal, a fim de perpetuar fatos históricos ou a evocar os grandes vultos civis ou militares da História Pátria.

5 - Premiais, concedidas por decretos do govêrno e destinadas a premiar o aluno classificado em primeiro lugar nas Academias Militares.

Para os que se dedicam ao estudo das Medalhas Militares, torna-se necessário possuir cultura de ordem técnica; sem o completo conhecimento dos decretos e, enfim, da própria legislação criada dos monumentos metálicos que, no caso vertente, são as medalhas militares, jamais poder-se-á fazer uma obra que sirva de ensinamento aos próprios colecionadores, desde os mais graduados ao incipiente (24).

Medalhas condecorativas
civis $\left\{\begin{array}{l}1-\text { comemorativas } \\ 2-\text { humanitárias } \\ 3-\text { premiais }\end{array}\right.$

1 - Comemorativas são as instituídas por sociedades civis, institutos culturais ou científicos e destinadas a glorificar

(24). - A Medalha de Bons Serviços ou Tempo de serviço, ê prêmio concedido ao militar pelos bons serviços prestados em tempo de paz, não encerrando esta medalha nenhum mérito de bravura. E' prêmio de reconhecimento aos serviços prestados à carreira das armas. Esta medalha é idêntica para tôdas as armas, isto é, Exército, Marinha e Aeronáutica.

Não deve ela ser confundida com a de Instrução Militar, pois enquan. to a primeira foi criada como "prêmio aos bons serviços prestados pelo militar", esta última procura galardoar o estudo, a conduta do agraclado em face de um decreto, de um aviso, de uma portaria que concede a distinção hoprosa. 
bons serviços prestados ou a reviver homenageando, os grandes vultos da História. Algumas são reconhecidas pelos Ministérios da República como de caráter oficial, por Portarias brixadas pelos respectivos ministros. Geralmente são de modêlo único, sem graus hierárquicos, raramente apresentando duas ou mais classificações; suas fitas também independem de aprovação pelo Ministério do Exterior, como no caso das fitas das Ordens honoríficas civis ou militares.

2 - Humanitárias são as instituídas por decretos dos governos da República ou dos Estados, para remunerar serviços extraordinários prestados à Humanidade, quer por ocasião de naufrágios e riscos marítimos, quer em casos de incêndios, de peste ou de qualquer calamidade pública.

3 - Premiais são as conferidas por entidades culturais ou escolas oficiais ou oficializadas de grau secundário ou superior. Em geral estas medalhas pendem de fitas com as côres racionais.

\section{MEDALHAS COMEMORATIVAS}

De forma circular, sem fita, são distribuídas como recordação ou homenagem a determinado acontecimento ou ainda evocando personalidades ligadas à história, às letras, às artes ou às ciências. Comemoram ainda inaugurações, centenários, jubileus, etc. Algumas medalhas dêste tipo têm sido distribuídas pelos Ministérios da República e dos Estados e outras ainda oficializadas pelos respectivos ministros, por Portarias ministeriais.

\section{PLAQUETES.}

São peças de forma retangular com as mesmas características e finalidade das medalhas comemorativas circulares, sem fita. 
COLARES.

Muito em uso nas instituições científicas, culturais e universitárias; são ostentados pelos seus titulares nas sessões solenes. Alguns são de rara beleza pela sua confecção.

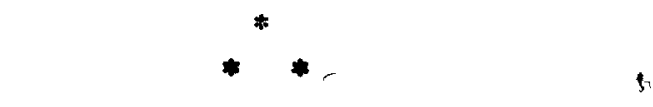

\section{MEDALHAS ESPORTIVAS.}

São as medalhas conquistadas em torneios esportivos, pendentes de fitas com as côres nacionais ou das entidades esportivas ou simples medalhas comemorativas. Algumas são instituídas pelos governos da República, dos Estados ou Municípios em caráter oficial.

As condecorações e as medalhas podem ser trabalhadas em platina, ouro, prata, vermeil (prata dourada), bronze e todo e qualquer metal resistente.

\section{GRADUAÇÓES DAS ORDENS HONORfFICAS.}

Em geral, as Ordens honoríficas compõe-se de cinco graus:

$$
\begin{aligned}
& 1 .^{\circ}-\text { Cavaleiro. } \\
& 2 .^{\circ}-\text { Oflicial. } \\
& 3 .^{\circ}-\text { Comendador. } \\
& 4 .^{\circ}-\text { Grande Oficial. } \\
& 5 .^{\circ}-\text { Grã-Cruz. }
\end{aligned}
$$

Em algumas Ordens existe ainda o grau de Grande Cordão e, em outras, além dos cinco graus já enumerados, o Colar no seu grau máximo, cuja insígnia é conferida a Chefes de Estado e as altas personalidades.

Existem entretanto outras Ordens que têm por insígnia sòmente o Colar em todos os seus graus, concedido indistintamente sem nenhuma determinação especial. 
Há também exceções; muitas Ordens têm essas cinco classes e outras menos de cinco; outras, em lugar dos graus de Comendador e Grande Oficial, possuem os de Comendador de 1a. e 2a. classe ou Comendador sem placa ou com placa.

O grau inicial, porém, é sempre o de Cavaleiro e as promoções aos diversos graus das Ordens processam-se paulatinamente, depois de determinado período de estágio.

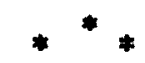

\section{COMO SE DISTINGUEM OS DIVERSOS GRAUS.}

O Cavaleiro usa a condecoração com ornatos de prata, pendente de fita simples sôbre o peito, do lado esquerdo.

O Oficial usa a mesma condecoração, porém, dourada e sôbre a fita uma roseta da mesma fita em idêntica posição.

O Comendador traz a condecoração pendente de uma fita ao pescoço, ficando a insígnia bem no centro do peito.

O Grande Oficial usa uma placa à altura da última costela, dr lado direito do peito.

O Grã-Cruz usa a mesma condecoração, perém dourada, na mesma altura, mas do lado esquerdo e um fitão ou banda com as côres da Ordem colocado em diagonal sôbre o peito, da direita para a esquerda, tendo na extremidade, abaixo da cintura e sôbre uma grande roseta com as mesmas côres do fitão ou banda, a insígnia da Ordem.

Devemos frisar que a grande maioria das Ordens honorificas nos seus mais elevados graus, costumam usar duas insígnias que se completam: a Grã-Cruz trazendo pendente a fita larga a tiracolo juntamente com a placa dourada e o Grande Oficial com a insígnia ao pescoço e a placa prateada. Muitas vêzes, entretanto, os desenhos são diferentes da primeira, sem contudo deixar de completar o grau estabelecido.

Existem ainda Ordens honorificas que conferem a Grã-Cruz simples e outras a Grã-Cruz com colar.

As condecorações do Império Brasileiro não incluiam a categoria de Grande Oficial, mas havia entre os graus de Comendador e a Grã-Cruz, as distinções de Dignitários e a de Grande Dignitário. 


\section{O USO DAS CONDECORAÇÓES.}

As condecorações nacionais têm precedência sôbre as estrangeiras.

"Assim, uma pessoa que possua condecorações nacionais e estrangeiras, colocará as nacionais antes das estrangeiras.

Para as nacionais a ordem é a seguinte; Ordens honoríficas, medalhas ou cruzes de mérito militar ou civil, medalhas de tempo de serviço e por último as comemorativas, obedecendo a precedência ao critério da antigüidade, isto é, a data da sua instituição, quando no mesmo grau, salvo se ao ser criada a condecoração lhe é prèviamente determinada a procedência, de outra forma prevalecerá o grau mais elevado. Por exemplo: um Oficial do Médito Naval, do Mérito Militar e da Ordem Nacional do Mérito, colocará em primeiro lugar a insignia do Mérito Naval, que é a mais antiga e por último a da Ordem $\mathrm{Na}$ cional do Mérito, que é a mais recente.

Se, porém, fôr Cavaleiro do Mérito Naval e Oficial do Mérito Militar e da Ordem Nacional do Mérito, a colocação já será outra: primeiro o Mérito Militar, depois a Ordem Nacional do Mérito e por fim o Mérito Naval.

Tratando-se de condecorações estrangeiras, o critério a seguir é o mesmo, apenas a ordem de procedência é regulada não pela antigüidade da instituição, mas sim pela data da sua concessão" (24).

Ao se alinharem as insígnias, devem as mesmas serem niveladas pelas peças e nunca pelo comprimento das fitas.

As senhoras nunca usam condecorações ao pescoço e nos outros vários graus, trazem-nas presas a um laço da respectiva fita, ao lado esquerdo do peito.

Para os possuidores de várias condecorações, o exibí-las na sua totalidade, seria impróprio e deselegante, devendo por isso o agraciado restringir-se a ostentar apenas as mais importantes, dependendo das circunstâncias.

O uso das condecorações militares, está previsto em regulamentos próprios.

(24a). - Orlando Guerrelro de Castro (ministro), Como usar as condecoraçoes. Publicação do Cerimonial do Ministérlo das Relaçóes Exteriores, Rio do anelro, 1956. 
Tôda a condecoração ou outra medalha condecorativa (com f:ta), só têm valor quando acompanhadas do respectivo diploma autenticado por quem de direito, registrado em livro especial e publicado no "Diário Oficial".

Quanto às medalhas comemorativas e plaquetes de caráter oficial, são elas acompanhadas de um certificado numerado e assinado pela autoridade que a concede.

\section{INTRODUÇĀO AO ESTUDO DAS ORDENS HONORFFICAS} BRASILEIRAS.

Transmigrando para o Brasil ao reflexo da espada de Junot, trouxe-nos o Príncipe Regente D. João entre outras muitas coisas e novidades, as tradicionais ordens militares de cavalaria lusitanas: Ordem de Nosso Senhor Jesus Cristo, Ordem Militar de Avís e Ordem Militar de São Tiago da Espada.

Estas três ordens foram aplicadas no Brasil em duas fases distintas: na primeira, durante o período colonial, quando o grão-mestrado pertencia aos soberanos portuguêses; a segunda, diretamente pelo govêrno brasileiro depois da Independência, vindo até a Proclamação da República.

Conservou o Império como única ligação com essas seculares Ordens portuguêsas, apenas a tradição dos seus símbolos e a própria designação e, embora as fitas das condecorações no Brasil Independente conservassem as mesmas côres das antigas Ordens lusitanas, diferenciavam-se destas por terem suas fitas orladas; as de Cristo e São Tiago da Espada de azul e a de São Bento le Avís, de vermelho.

Assim, excetuando-se as Ordens da Tôrre e Espada e de Santa Isabel da época colonial e a de Nossa Senhora da Conceição de Vila Viçosa do Brasil Reino, instituída em homenagem à padroeira do Reino de Portugal, as outras três foram consideradas como nacionais quando proclamada a liberdade do nascente Império, de acôrdo com a ampla disposição da lei de 20 de outubro de 1823 , que estabelecia no seu Artigo $1 .^{\circ}$ o seguinte:

"As ordenações, leis, regimentos, alvarás, decretos e resoluções promulgadas pelos Reis de Portugal e pelas quais o Brasil se governou até 25 de abril de 1821 , em que $S$. M. F., o atual Rei de Portugal e Algarves, se ausentou desta Côrte e tôdas as que foram promulgadas daquela data em diante pelo Sr. D. Pedro de Alcântara, e como 
Imperador Constitucional dêle, desde que se erigiu em. Império, ficam em inteiro vigor na parte em que nāo tiverem sido revogados, para por êles se regularem os negócios do interior dêste Império, enquanto se não organizar um novo Código ou náo forem especialmente alterados".

Pela Bula Pontifícia do Papa Leão XII, de 30 de maio de. 1827 - Praeclara Portugalliae et Algarbiorum Regum - foram as Ordens de Nosso Senhor Jesus Cristo, São Tiago da Espada e São Bento de Avís separadas de Portugal e nacionalizadas e" o seu grão-mestrado conferido aos imperadores do Brasil que não o aceitaram, pur ter a Bula sido prejudicada pela negativa: do beneplácito da Assembléia Geral.

Manteve-se o statu quo até 1843 , quando D. Pedro II, maior, declarou as Ordens lusitanas, brasileiras, com caráter civil e. político e não mais religioso, dando-lhes uma regulamentação. definitiva pelo decreto $n$. 321 , de 9 de setembro de 1843 , que. estabelecia:

"Art. 1.0 - As Ordens Militares de Cristo, São Bentor de Avís e São Tiago da Espada ficam de ora em diante tidas e consideradas como meramente civis e politicas, destinadas para remunerar serviços feitos ao Estado, tan-. to pelos súditos do Império como por estrangeiros bene-. méritos".

Em 1861, José Ildefonso de Souza Ramos, senador e secretário de Estados dos Negócios do Império, pelo decreto n. 2.853, de 7 de dezembro, regulamentava a concessão das ordens honoríficas do Império Brasileiro; ninguém podia nelas ser admitido sem requerimento comprobatório de vinte anos de serviços não remunerados, salvo os párocos colados que se tivessem. distinguido por suas virtudes e zêlo no desempênho do seu ministério que seriam admitidos na Ordem de Cristo, após dez. arios de serviço.

Outro decreto de n. 4.144, datado de 5 de abril de 1868 e referendado por João Lustoza da Cunha Paranaguá, ministro e Secretário de Estados dos Negócios da Guerra, regulamentando a concessão da Ordem de São Bento de Avís, assim se expressava:

"A Ordem de São Bento de Avís é exclusivamentedestinada a remunerar serviços militares".

Esta Ordem passou a ser concedida a oficiais com vinte anos de serviço sem nota de qualquer desdouro, extensivas as 


\section{MEDALHAS CONDECORATIVAS MILITARES.}

Fig. 8. - Medalha Militar de Bons Serviços. Na fita, passador com quatro estrêlas de platina correspondendo a 40 anos de bons serviços nas classes armadas.
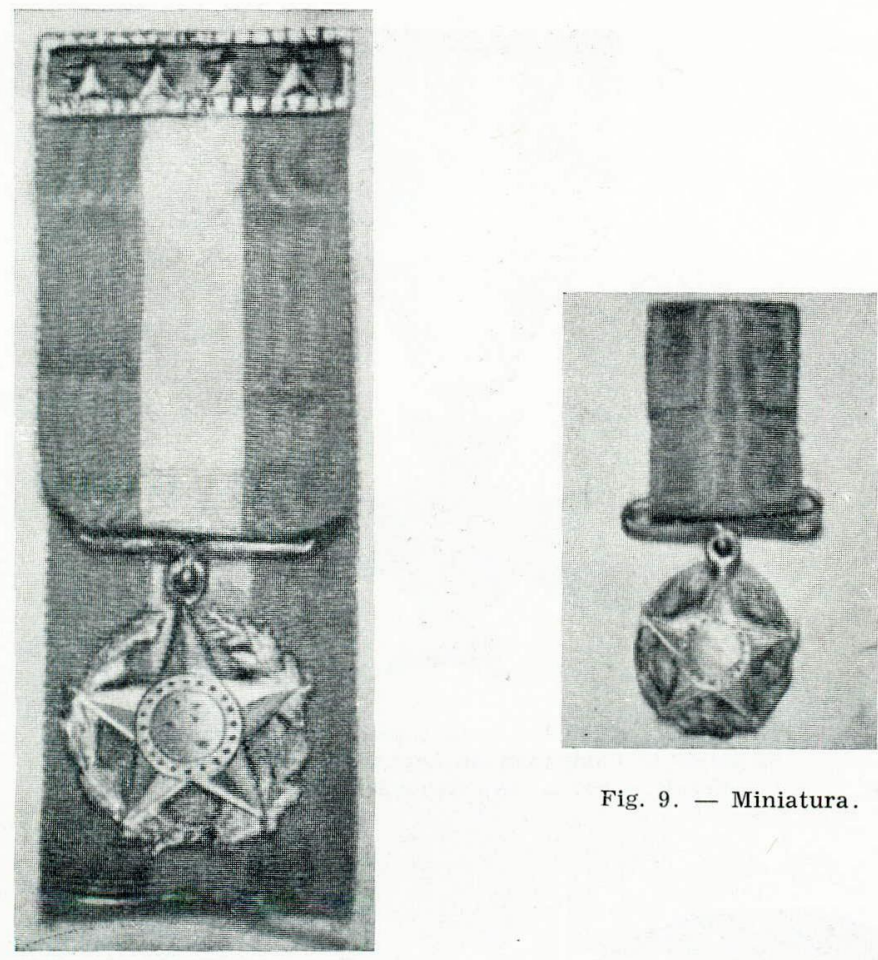

Fig. 9. - Miniatura .

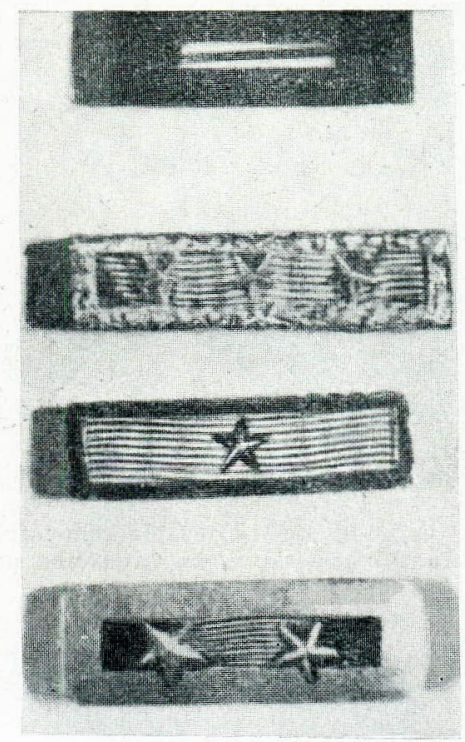

Fig. 10. - Passadores.

1 estrêla de bronze, 10 anos de bons serviços.

2 estrêlas de prata, 20 anos de bons serviços.

3 estrêlas de ouro, 30 anos de bons serviços. 


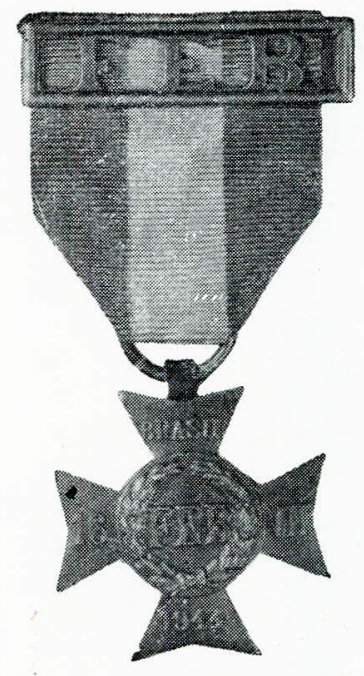

Fig. 11. - Medalha condecorativa de campanha. Medalha de Campanha da Segunda Guerra Mundial. F.E.B. (Fôrça Expedicionária Brasileira).
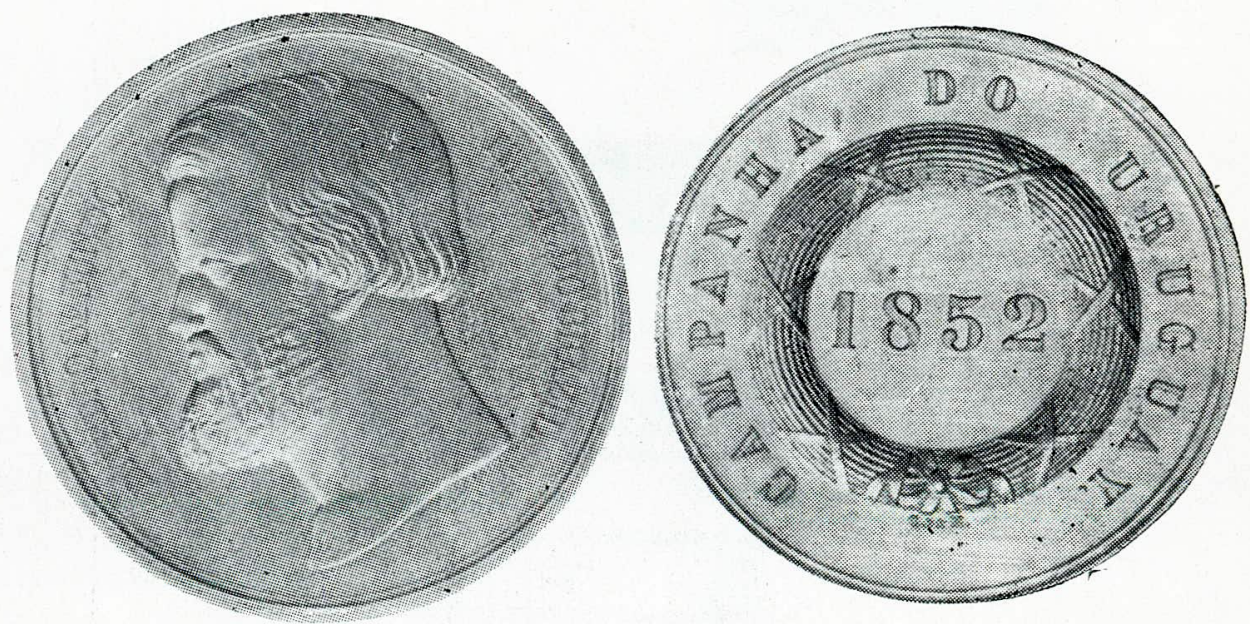

Fig. 12. - Medalha comemorativa.

Medalha Comemorativa da Campanha do Uruguai. 1852. 

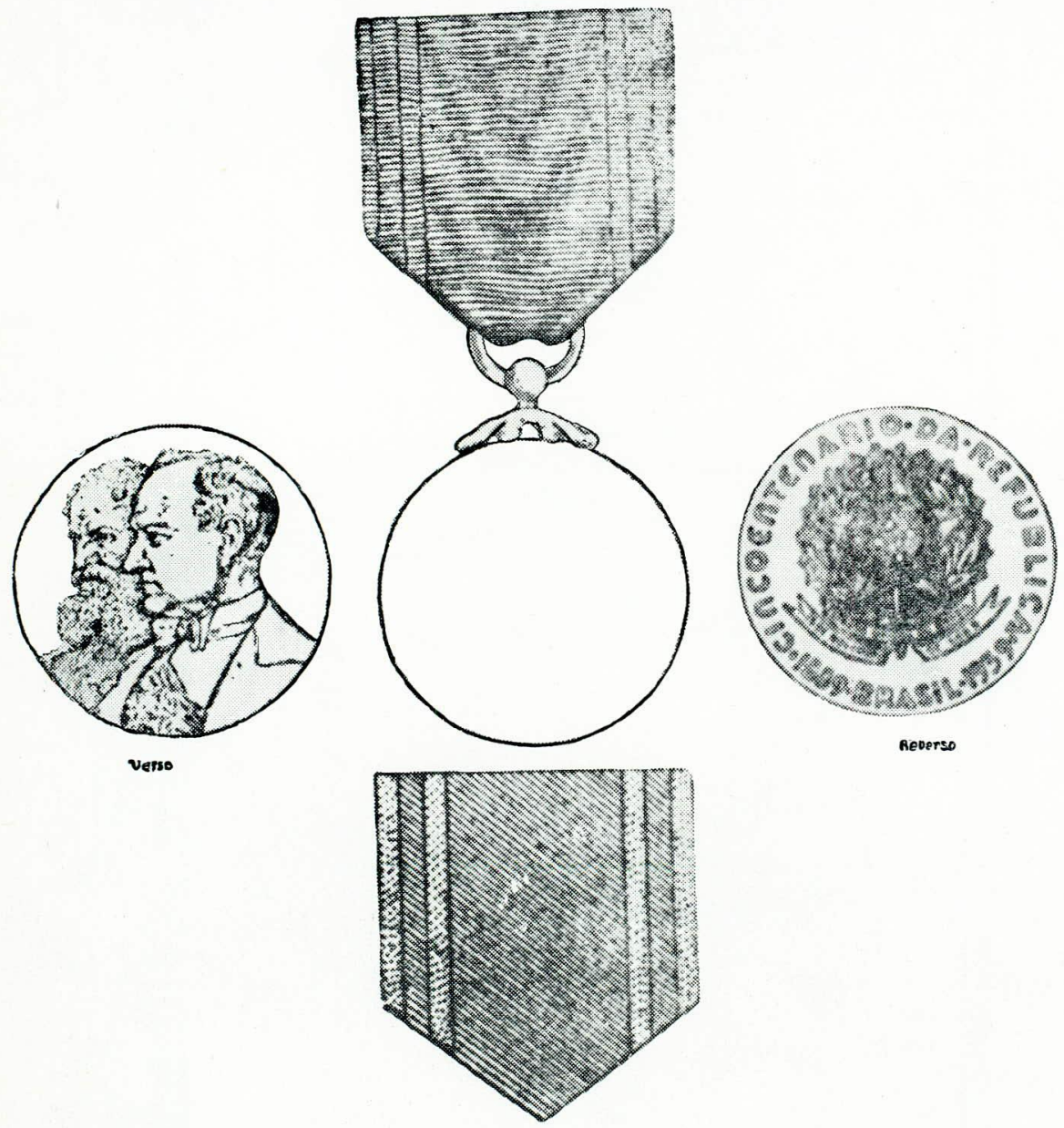

Detalhe da fita (beraldien)

\section{NoTA: Tamanho natural.}

Fig. 13. - Medalha condecorativa civil.

Medalha Comemorativa do Cinquentenário da República.

(Do Govêrno Federal). 
mesmas condições aos corpos de Saúde e eclesiástico do Exército. Após minucioso exame de documentos, o Conselho Supremo Militar se pronunciaria, em parecer motivado, pela concessão ou recusa do hábito de Avís.

Este decreto foi depois extensivo aos oficiais da Armada Imperial, como se lê no regulamento baixado em 13 de junho de 1868, de n. 4.203, referendado por Afonso Celso de Assis Figueiredo, ministro e Secretário de Estado dos Negócios da Marinha:

"A concessão da condecoração de Ordem de Avís para os Oficiais da Armada, será feita independente de requerimento, observando-se o seguinte:

1.0 - Logo que qualquer Oficial completar o tempo de serviço de que trata o presente Decreto, o Quartel General da Marinha remeterá a respecitva Fé de Ofício, convenientemente informada, ao Conselho Naval".

Da mesma maneira, a Ordem de São Tiago da Espada destinou-se a recompensar serviços relevantes prestados à ciência, às letras e às artes.

Assim, as três velhas Ordens Militares de Portugal, de brilhante passado e tão ligadas à história da fundação da Monarquia, à recuperação do território português e ao descobrimento de novos mundos para a civilização, foram por fôrça de decretos consideradas brasileiras até ao crepúsculo do Império.

Reconhecida nossa Independência pela monarquia portuguêsa, da qual havíamos sido colonialmente parte de magnitude bem secular, caberia ao nosso primeiro imperador D. Pedro I, criar ordens honoríficas genuinamente brasileiras e que subsistiram até à Proclamação da República em 1889.

Foram três as Ordens: Imperial Ordem do Cruzeiro; Ordem de D. Pedro I Fundador do Império do Brasil e a Imperial Ordem da Rosa.

A primeira datando de 1822 ; a segunda, de 1826 e a terceira de 1829, cujos decretos foram referendados por José Bonifácio de Andrada e Silva, José Feliciano Fernandes Pinheiro e José Clemente Pereira, respectivamente.

A primeira, a que mais de perto fala ao nosso patriotismo de brasileiros, foi instituída por decreto de 1 de dezembro de 1822, para: 


\begin{abstract}
"assinalar por um modo solene e memorável a época da Minha Aclamação, Sagração e Coroação, como Imperador Constitucional do Brasil e seu Perpétuo Defensor".
\end{abstract}

O nome de Cruzeiro foi dado em alusão à posição geográfica da vasta e rica região da América austral que formava o Império do Brasil, onde dominava a grande constelação do Cruzeiro, e igualmente em memória do nome primitivo de Terra de Santa Cruz.

A segunda foi criada por decreto de 16 de abril de 1826, para:

"marcar de uma maneira distinta, a época em que foi reconhecida a Independência dêste vasto Império, que tive a glória de fundar, e do qual sou o primeiro Imperador Constitucional".

Foi esta a condecoração mais rara do Império e só excepcionalmente foi dada a dois brasileiros: ao marquês de Barbacena no primeiro reinado e no segundo, ao duque de Caxias, quando de seu regresso da campanha do Paraguai.

A terceira nasceu de um ato de galanteria de nosso primeiro Imperador. Dizia o decreto de 17 de outubro de 1829:

"querendo perpetuar a memória do Meu faustíssimo consórcio com a Princesa Amélia de Leuchtenberg e Eischstoedt".

Tôdas as nossas condecorações imperiais eram bonitas, porém, a da Rosa a mais delicada.

Constava esta condecoração de uma estrêla de seis raios, tendo ao centro um monograma formado pelas iniciais entrelaçadas A. P. (Pedro e Amélia). Contornando, a legenda: Amor e Fidelidade, descansando as extremidades dos raios da estrêla sôbre uma corôa de rosas.

Os graus mais elevados da Imperial Ordem da Rosa eram os de Grã-Cruz e Grande Dignitário, parcamente concedidos. Ninguém podia ser Grã-cruz sem ter já por algum título o tratamento de Excelência, usado de jure pelos Grandes Dignitários da Ordem.

Nos dias solenes da Côrte ou nos de grande gala, os Grãcruzes efetivos usavam banda côr de rosa - côr do traje de D. Amélia ao desembarcar no Rio de Janeiro - por sôbre a casaca ou farda. Mas o que lhes dava maior realce, era o Colar formado de rosas de ouro e de esmalte. Não o dispensava nos atos solenes o almirante Tamandaré. Aliás, ia muito bem o Co- 
lar no varão ilustre, encanecido nas lutas do mar, face de bravo, cabelos brancos esvoaçando de tão finos, barba alvejante, todo de resistência ao inevitável declínio.

Durante o Segundo Reinado não foram criadas Ordens honoríficas.

No Império tôdas as medalhas e condecorações brasileiras eram usadas pendentes, isto é, pendiam do lado esquerdo do peito, norma estabelecida para os oficiais e praças de pret; exceção feita para a medalha aos mais bravos, que era pendente do lado direito. Os generais lançavam-nas ao pescoço (em grande gala) pendentes de fitas mais largas, presas atrás dos fardões por colchetes ou fechos de ouro.

Tôdas as medalhas do Primeiro Reinado pendiam de fitas com as côres nacionais. Amarela, verde, verde orlada de amarelo e listrada de verde e amarelo.

Um dos primeiros atos da República foi o extermínio das mercês honoríficas do regime monárquico. Dizia o decreto do. Govêrno Provisório de n. 277 F, de 22 de março de 1890:

"ficam abolidos todos os títulos, foros de nobreza e ordens honorificas estabelecidas pelo antigo regime".

Sem embargo da inocente perseguição, Deodoro da Fonseca, o Fundador da República, apresentava-se em público ou retratava-se com as veneras do Império.

O mesmo decreto, porém, abria uma exceção para as Ordens de São Bento de Avís e a do Cruzeiro, as quais deviam permanecer

$$
\begin{aligned}
& \text { "com tôdas as honras, direitos e isenções indicadas } \\
& \text { na legislação que as criou". }
\end{aligned}
$$

O Govêrno Provisório da República, não contente com a ressalva do citado decreto, instituia por decreto n. 456, de 6 de junho de 1890, uma nova Ordem honorífica civil e militar der.ominada Ordem de Colombo, em homenagem ao descobridor da América, conquanto não se conheça até agora nenhum modêlo oficial de suas insígnias. $O$ decreto referente à instituição desta Ordem, dizia:

"para os gran-cruzes efetivos, colar formado alternadamente por dois CC entrelaçados e corôas de louro, tendo pendente a medalha da ordem; banda passada da di- 
reita para a esquerda, de côr azul celeste, cortada ao meio por outra estreita, de côr verde, orlada de encarnado, com a medalha pendente; medalha no lado esquerdo".

A medalha, segundo o mesmo decreto, era uma estrêla como a do Cruzeiro, esmaltada de branco, assentada sôbre raios do prata e encimada por uma de ouro, tendo no centro, em campo azul ferrete as letras CC (Cristóvão Colombo) de ouro, entrelaçadas.

Desta Ordem foram concedidos sòmente diplomas nos seus vários graus, a diplomatas e cônsules franceses, na Europa, no Rio de Janeiro e em Pernambuco.

Não tardou, porém, a ser votada a Constituição de 1891, declarando teòricamente todos iguais perante a lei, proscrevendo privilégios de nascimento, extinguindo as ordens honoríficas existentes com tôdas as suas prerrogativas e regalias, bem como os títulos nobiliárquicos e de Conselho. A rasoura constitucional passou sôbre a venera de Colombo. Mal teve tempo a Ordem do Descobridor da América para ser descoberta em qualquer peito de agraciado. Ficou sendo ùnicamente Ordem de vitrina.

"Os homens que modificaram no Brasil, em 1889, a estrutura politica do Estado, entenderam que com a monarquia deveria desaparecer tudo o que, mesmo ao de leve, a suscitasse. Esqueceram-se momentâneamente de que as nações não podem relegar por simples decretos antigas e estimadas tradições, cumprindo-lhes, ao contrário, lançar e firmar raizes no passado, para dai retirarem a seiva que alimentará o patriotismo, fomentará o orgulho cívico, estimulará e manterá sempre vivo o amor à Pátria. E, com os títulos de nobreza, que não era de sangue - mas militar, política, artística e rural - aboliram-se pela constituição republicana as dignidades das ordens honorificas, cujas veneras por tantos anos brilharam sôbre o peito de nossos soldados, de nossos homens de Estado, de nossos artistas e cientistas - todos dedicados artífices da grandeza nacional no Império. $\mathbf{E}$ a proibição não se limitou às nossas condecorações; sob. pena de perda dos direitos politicos, era vedada a aceitação de prêmios dessa natureza concedidos pelos governos estrangeiros.

Contra êsse ponto de vista geral e dominante, encontramos a figura do Fundador da República mantendo antigas ordens e criando novas e com elas premiando dedicações e serviços revalidando títulos nobiliárquicos e 
assegurando as suas prerrogativas. Mas acabou cedendo" (25) .

Em 1922 quando pelas festas do I Centenário da Independência tentou o govêrno da República presidido pelo dr. Epitácio da Silva Pessoa restabelecer a Ordem do Cruzeiro, não o conseguiu tal a oposição encontrada no Congresso Nacional. Passados anos, êsse conceito tão radical quanto errôneo, modifica-se. A 5 de dezembro de 1932, o govêrno do dr. Getúlio Vasgas restabelecia a mais brasileira de tôdas as Ordens honoríficas, criando duas novas "sem prejuízo do espírito republicano da Nação".

Era finalmente restabelecida a Ordem Naciontal do Cruzeiro do Sul, na realidade, a mais brasileira de tôdas as Ordens hororíficas. Do povo brasileiro tornou-se a Cruz o símbolo nacional. Vera Cruz e Santa Cruz foram os primeiros nomes da terra descoberta por Cabral e o próprio descobrimento, depois da mudança do calendário, passou a ser comemorado a 3 de maio - festa da Santa Cruz. Mais tarde, plasmada a nova nacionalidade, buscou-se a imagem do Cruzeiro para definir a Nação, na bandeira, no brasão de armas e na sua mais alta condecoração nacional. Dezenas de cidades, por todo o País, tem seu nome ligado ao do Santo Lenho e, sobretudo, nossa gente cresceu e se conserva fiel ao culto da Cruz de Cristo, símbolo vivo de sua fé católica.

Em seguida foram instituídas a Ordem do Mérito Naval e a Ordem do Mérito Mlilitar e outras mais, tôdas recompensando e estimulando o mérito nos diversos setores da atividade humana.

Desejamos aqui esclarecer que as antigas Ordens Militares Brasileiras de Cristo e Avis, são na América, as únicas que vêm da Idade Média e atravessaram o Atlântico nas gloriosas caravelas e naus dos descobrimentos.

Também na época colonial, as condecorações das Ordens de Cristo, São Bento de Avís e São Tiago da Espada, eram tôdas em pedrarias e cravadas em ouro e prata.

Foi durante o reinado de D. Maria I (1786-1799) que essa soberana, por devoção especial ao Sagrado Coração, mandou encimar por êste símbolo as veneras das três Ordens: Cristo, Avís e São Tiago da Espada.

(25). - Lufs Marques Poliano, Ordens Honorificas do Brasil. Imprensa Nacional, Rio de Janeiro, 1943. 
No presente trabalho sôbre condecorações, iremos estudar: a história, organização e a legislação de cada uma e para isso, dividimos êste estudo nos seguintes capítulos:

1 - Ordens militares portuguêsas renovadas e outras criadas por D. João, Príncipe Regente, depois D. João VI, no govêrno do Rio de Janeiro.

2 - Ordens militares portuguêsas vindas para o Brasil com D. João, Príncipe Regente e tidas como Ordens brasileiras no Império.

3 -- Ordens honoríficas do Império instituídas pelo Imperador D. Pedro I e extintas com a Proclamação da República.

4 - Ordens honoríficas da República.

5 - Medalhas militares do Brasil Colônia, Reino, Império e República.

6 - Medalhas condecorativas.

7 - Medalhas comemorativas de valor científico e cultural.

8 - Medalhas das Fôrças Policiais dos Estados da União.

9 - Colares de instituições científicas e universitárias.

(Continua no próximo número). 